\title{
Review on the Financing Scheme of Indonesia's Capital City Relocation Plan: Lessons Learned from Brazil, Malaysia, and Tanzania
}

\author{
M Ridho Mubaroq ${ }^{1}$ and Akhmad Solikin ${ }^{2}$ \\ \{mridhomubaroq@gmail.com ${ }^{1}, \underline{\text { akhsol@pknstan.ac.id }}{ }^{2}$ \} \\ ${ }^{1}$ Fiscal Policy Agency \& Polytechnic of State Finance STAN, Ministry of Finance of Indonesia Jakarta, \\ Indonesia \\ ${ }^{2}$ Polytechnic of State Finance STAN, Ministry of Finance of Indonesia South Tangerang, Indonesia
}

\begin{abstract}
To distribute the nation's wealth fairly and to separate the administrative capital from center of business, Government of Indonesia is reviving the long-discussed plan of capital city relocation. The plan could cost around IDR200-300 trillion or about 13-14 per cent of 2018 state budget. The figure is quite significant and potentially disrupts budget allocation for priority programs if the plan is carried out without the thorough calculation on its financing scheme. This paper first seeks for the lessons learned on the financing scheme from both successful and failed stories of capital city relocations, mainly focuses on successful Brazil's and Malaysia's experience and botched Tanzania's plan. Furthermore, this paper tries to find the connection between the lessons learned and the current situation in Indonesia, including its economic condition and the legal aspects, so as to get the best possible financing scheme. Analyzing the interview data with the qualitative method, this paper concludes that both resources from government and private sectors are needed in order to conduct the plan smoothly. According to the resource persons, the ideal proportion between budget and public private partnership are varies and each proportion may face different obstacles. Importantly, the government's commitment plays a strong part in influencing the outcome of this long-overdue plan.
\end{abstract}

Keywords: Capital relocation, Budget expenditure, Private sectors, Public private partnership

\section{Introduction}

The plan to move the capital city seems to be a mandatory issue that always revolves around every government in Indonesia. Starting with the planned move of the capital city to Palangkaraya in the government of President Soekarno, followed by plans to make Jonggol a replacement of the DKI / Special Region City of Jakarta in the administration of President Soeharto and President Susilo Bambang Yudhoyono, and no exception the Joko Widodo government has plans to move it as well (Sugianto, 2017). The Head of Bappenas announced on July 3, 2017 that Bappenas was discussing together with President Joko Widodo regarding the planned relocation of the capital (Aziza, 2017). The Head of Bappenas promised that the study of the capital transfer scheme would be completed by the end of 2017, so that the capital transfer process could begin in 2018 or 2019.

There are at least two reasons why the transfer of the capital city needs to be carried out according to the Government. The first reason is to do economic equality (Ariyanti, 2017). At present, the imbalance in economic activities between the Jabodetabek area and other regions is very high. This was indicated by Jakarta's contribution to Indonesia's Gross Domestic 
Product (GDP) which reached 18 percent. If it is added to the Jabodetabek area, the contribution will be 25 percent of GDP. The second reason for the effort to move the capital city is to separate the center of government from the business center, as stated by the Minister of Public Works and Public Housing (PUPR) (Taufiqqurahman, 2017). Through the separation between the central government and the business center, it is hoped that governance can run more effectively and efficiently.

Minister of PUPR said that around IDR200-300 trillion is needed to move the capital city of the country (Daud, 2017). This amount is certainly not small because it reaches $13-14 \%$ of the total government expenditure in the 2018 State Budget which amounts to around IDR 2,220 trillion. However, the Head of Bappenas stressed that the government would involve the private sector (Nababan, 2018). In other words, the capital transfer scheme does not only depend on the state budget, but also comes from funds owned by the private sector. The concept is better known as Public Private Partnership (PPP). Indonesia also has known and implemented the concept in the name of Government-Business Cooperation.

Determining the right financing scheme will facilitate the government's step in managing a professional budget. Based on the principle of cost-benefit analysis, (Boadway, 2006) it is necessary to avoid that this policy actually has fewer benefits than the costs to be borne through budget allocation in State Budget that are not appropriate, so that it will burden the state budget which can actually be allocated to other sectors, such as education, health, and infrastructure.

Based on the description above, learning from other countries that have moved the capital city can be used as a consideration for the government in choosing the right financing scheme, whether it is purely using the state budget or Government-Business Cooperation scheme. Not only the story of the successful relocation of the capital city, but also the experience of other countries that failed or were hampered in executing the planned transfer of the capital city. Even a successful capital city relocation does not always reach the original goal when the plan was announced.

This paper will review the processes carried out in the relocation of capitals in Brazil, Malaysia, and Tanzania, especially in terms of the total costs already incurred as well as the financing mechanism selected based on the plan and purpose of the transfer and the situation and conditions of the country. Brazil and Malaysia were chosen as best practices in this paper because of their success in moving the capital (for Brazil) and separating the business and government centers (for Malaysia), while Tanzania has not succeeded to transfer the new capital city that has been declared since 1974. The fact that those three are developing countries is suitable to be compared to Indonesia.

After learning from the advantages or disadvantages of these practices, this paper will compare the lessons learnedto Indonesia's plan, so that the appropriate financing scheme for the plan in moving the Indonesian capital can be obtained. Options for discussion of financing schemes will be focused between financing using a pure state budget and through a Government-Business Cooperation scheme.

\section{Literature Review}

\subsection{Definition of Capital}

In English, the term capital city is called capital. The capital is taken from Latin, which is caput, which means head and capitol related to the building where the main government center is carried out. The capital city is the main city associated with the governance of a country, 
physically functioned as a central office and meeting place and determined by law. The existence of a capital city is seen as the main city of a country and needs special treatment when compared to other cities. This was revealed in (Gottmann, 1997): "The capital is by definition the place where major decisions are taken which relate the political entity governed and its inhabitants, resources and institutions to the world beyond its boundaries. The capital is a crossroads where sets of internal and external relationships and networks interlock and interact”.

The capital city also tends to have a larger location, both region and population compared to other cities in the country (Quistorff, 2015). This is reasonable considering the enormous influence that the capital city has on determining the present and future of a country (Gottmann, 1997). For example, in the Middle Ages, the existence of capitals in continental European countries tended to be a tool for tyrannical rules to regulate and supervise other regions (Herbst, 2014). In addition to the area and population, the capital city of a country is generally located in cities that have the highest welfare level in the country. In addition, the capital city is not only seen as the largest, most developed and rich city of a country, but the capital city is a major reflection of the country and has a value that can be proud of internationally (Oliver, 2012).

\subsection{Reasons for Moving the Capital}

In this century there are thirteen countries that have moved their capitals for various reasons. Countries that move the capital are listed in Table 1.

Table 1. List of Countries That Have the Capital Relocation in The $20^{\text {th }}$ Century

\begin{tabular}{llll}
\hline \multicolumn{1}{c}{ Country } & Years & New Capital City & Old Capital City \\
\hline Brazil & 1956 & Brasilia & Rio de Janeiro \\
\hline Mauritania & 1957 & Nouakchott & $\begin{array}{l}\text { Saint Louis } \\
\text { (Senegal) }\end{array}$ \\
\hline Pakistan & 1959 & Islamabad & Karachi \\
\hline Botswana & 1961 & Gaberone & Mafeking \\
\hline Libya & 1963 & Tripoli & Benghazi \\
\hline Malawi & 1965 & Liliongwe & Zomba \\
\hline Belize & 1970 & Belmopan & Belize City \\
\hline Tanzania & 1973 & Dodoma & Dar es Salaam \\
\hline Nigeria & 1975 & Abuja & Lagos \\
\hline Pantai gading & 1983 & Yamoussoukro & Abidjan \\
\hline German & 1990 & Berlin & Bonn \\
\hline Kazakhstan & 1997 & Astana & Almaty \\
\hline Malaysia & 2000 & Putrajaya & Kuala Lumpur \\
\hline \multicolumn{5}{c}{ Source: Compilation of authors }
\end{tabular}

There are at least five possibilities why a country moves its capital location based on indepth studies conducted on the African continent (Schatz, 2003), namely:

- Preference from country leaders

One of the reasons behind the transfer of the capital city was the preference of the president in authoritarian rule as did Malawi (Potts, 1985). Preference from the leaders of the country is more inclined to personal pride than to think of rational reasons such as economic restructuring of the country. 


\section{- Logical reasons and rationalization}

The logical and rational reason for moving the capital city is to improve the economy and improve the function of state administration (Oliver, 2012).

- Building "state building" and "nation building"

State building meant by (Schatz, 2003) is an attempt to fight resistance from political rivals. Meanwhile, nation building is an attempt to secure the loyalty of its supporters in a new place where the capital will be moved.

- Infrastructure Financing through Government-Business Cooperation

The implementation of national development is one of the mandates of the Constitution that must be borne by the government. Barton in (Prasetya, 2012) outlines the main role of government in general, including the role of resource allocation and the role of social welfare. The role of resource allocation and the role of social welfare in general emphasize that the government must be able to provide public goods and social welfare services for the community. Adam Smith in (Prasetya, 2012) also emphasized that the government must be able to provide goods that cannot be provided by the private sector, one of which is by providing qualified infrastructure for its people. The limitations of the state budget require the involvement of other parties in participating in financing this government program. It is noted in the RPJMN that the five-year infrastructure requirement is IDR 5,500 trillion, or if it is averaged it becomes IDR 1,100 trillion per year. The amount of the figure is beyond the ability of the state's finances, which if collected from the state budget, the budget of the state own enterprises, and other investments only reach Rp900 trillion each year. The Head of Bappenas added that the infrastructure budget was even revised to IDR 4,700 trillion, with the proportion of one-third of the state budget, $25 \%$ from state own enterprises, and the remaining participation from private parties such as GovernmentBusiness Cooperation (Fitra, 2017).

To support infrastructure provision through Government-Business Cooperation, the Government established Presidential Regulation number 38 of 2015 concerning Government Cooperation with Business Entities in the Provision of Infrastructure. There are several principles that must be met so that project financing can be financed in the form of Government-Business Cooperation, including: (i) Partnership; (ii) Benefits; (iii) Competing; (iv) Risk control and management; (v) effective; and (vi) efficient.

The principle of partnership is one of the principles that is difficult to fulfill so that project financing can take the Government-Business Cooperation schemes. In its consideration to execute a public facility project with the government, the private sector always considers several factors, namely financial feasibility, clarity of the scope of cooperation, and guarantees of risk (Indrawati, 2018).

\section{Methodology}

This research uses descriptive qualitative method. The Smart Practice Research method introduced by Bardach in (Veselý, 2011) was also used to explore lessons learned from Brazil, Malaysia and Tanzania. Primary data was obtained by interviewing: (i) representatives of Brazilian and Malaysian embassies and the Indonesian Ministry of Foreign Affairs to obtain and verify information related to the relocation of capitals in Brazil, Malaysia and Tanzania; (ii) the Ministry of PUPR to obtain information related to the plan to move the capital city in Indonesia; (iii) Directorate General of Budget and Fiscal Policy Agency, Ministry of Finance to explore the possibility of using traditional schemes (state budget); and (iv) Directorate General of Financing and Risk Management, Ministry of Finance and academics to explore 
the possibility of using Government-Business Cooperation schemes. Secondary data is obtained from the literature and relevant public documents.

\section{Result And Discussion}

\subsection{Plan for Capital Relocation in Indonesia}

Based on the narrative speaker, the study being explored by Bappenas, Ministry of PUPR, and other institutions is about the study of the relocation of the center of government, not the capital as a whole, from the Special Region of Indonesia (DKI) Jakarta to other regions in Indonesia. The basis of Indonesia needs to move the center of government, among others: (i) to realize a prosperous Indonesia and justice with a sustainable growth economy; (ii) to foster new approaches epicenter disadvantaged areas and the suburbs; (iii) to facilitate the restructuring of Jakarta and other major cities in Java; (iv) to protect agricultural land in Java because of its highest fertility rate among other regions in Indonesia; and (v) to prevent the occurrence of social shocks, reduce the effects of climate change, and reduce the level of urbanization.

Table 2 presents the projected recapitulation of the cost of moving the capital city with a total of IDR 690 trillion, which is planned to be completed in the tentative period of 30 years following with the source of financing.

\subsection{Smart Practices on Relocation of the Capital City}

\subsubsection{Brazil}

The Brazilian Constitution in 1891, 1934 and 1946 suggested that the Brazilian capital be moved to a location closer to the center of the country (Morten and Oliveira, 2016). The reason for the relocation of the capital is to improve the regional economy, promote nationalism, reduce population density, receive too much attention from domestic and international, and reduce the risk of military attacks from the sea (Morten and Oliveira, 2016).

Table 2. Recapitulation of Government Capital Transfer Cost

\begin{tabular}{|c|c|c|}
\hline No & Function & Cost \\
\hline \multicolumn{3}{|c|}{ Funded by the state budget: IDR 420 trillion } \\
\hline 1 & $\begin{array}{l}\text { Main } \\
\text { (Legislative, Executive } \\
\text { and Judicial Buildings) }\end{array}$ & IDR 40 trillion \\
\hline 2 & $\begin{array}{l}\text { Supporting } \\
\text { (Housing for Low- } \\
\text { Income Communities } \\
\text { (MBR), Schools and } \\
\text { universities, Hospitals } \\
\text { and health centers, } \\
\text { environmental security, } \\
\text { and POLRI and TNI } \\
\text { buildings) }\end{array}$ & IDR 300 trillion \\
\hline 3 & $\begin{array}{lr}\text { Supporting } & \text { Functions } \\
\text { (Construction of roads, } \\
\text { Construction }\end{array}$ & IDR 80 trillion \\
\hline
\end{tabular}




\begin{tabular}{|c|c|c|}
\hline & $\begin{array}{lr}\text { Integrated } & \text { Waste } \\
\text { Treatment } & \text { Plants, } \\
\text { Drinking } & \text { Water } \\
\text { Treatment, } & \text { Waste } \\
\text { Management, } & \text { and } \\
\begin{array}{l}\text { Drainage Systems } \\
\text { green open spaces) }\end{array} & \text { and } \\
\end{array}$ & \\
\hline \multicolumn{3}{|c|}{ Financed by the private sector: Rp. 270 trillion } \\
\hline 1. & $\begin{array}{l}\text { Land and Housing (for } \\
\text { supporting } \text { economic } \\
\text { actors) }\end{array}$ & IDR 50 trillion \\
\hline 2. & $\begin{array}{l}\text { Land and Flats / } \\
\text { Apartments (ASN and } \\
\text { family) }\end{array}$ & IDR 220 trillion \\
\hline
\end{tabular}

The relocation of the Brazilian capital was realized during the administration of Juscelino Kubitschek (1956-1961). Development in Brasilia began in 1956, the beginning of the Kubitschek administration, and was inaugurated on April 21, 1960 (Epstein, 1973). The relocation of the capital occurred because the Kubitschek government hoped for several things that had been suggested by the Brazilian constitution above. The move took place more because of political promises made by Kubitschek during the campaign period to be chosen by the Brazilian people as president, without prior in-depth study (Epstein, 1973). Brasilia itself is a manifestation of the Kubitschek work program called the "Goals Plan" or Plano de Metas which the development of Brasilia is expected to be a synthesis of all development goals during the five years of the Kubitschek's administration.

Located in the interior and must start from scratch, the Brazilian government must burden the country's budget with a large amount in order to carry out the relocation of the capital city. Considering that the official data of the Brazilian Government only entered the international scope in 1985, no accurate figures were obtained regarding the exact amount of the total cost of moving the capital city. It is estimated that the cost required is $2-3 \%$ of Brazil's total GDP at that time or around USD 400-600 million (Gordon, 2006). This figure is quite large so it took years for the Brazilian Government to recover from the total cost.

The total funds all come from the government budget, both through the issuance of currency and loans. The Brazilian government also built a company to oversee the construction of Brasilia from the beginning to the end, namely Novacap, which still operates until today.

\subsubsection{Malaysia}

Built in 1995 and formalized in 1999, Putrajaya is part of an ambitious project implemented by Prime Minister Mahathir Mohamed to make Malaysia a developed country by 2020, with its program called Insight 2020 or better known as Vision 2020 (Moser, 2010). Putrajaya is also expected to bring Malaysia on the international stage so that it can attract a lot of foreign investment in Malaysia and the Malaysian economy will also be boosted ((Olds, 1995; Morshidi and Pandian, 2007)

In addition, Putrajaya is expected to become a "city model" which is a model for other countries in Asia, especially Southeast Asia(Moser, 2010). Through Putrajaya, Malaysia also 
tried to define the identity of its country as one of the advanced Muslim countries in the world. No wonder the development in Putrajaya is more of a modern Islamic architectural nuance because Malaysia wants to accentuate its image as a Muslim country with technological advances (Moser, 2010).

Being part of the Vision 2020 mega project made the costs incurred to make Putrajaya the center of government administration in Malaysiaquite big. In general, the Government of Malaysia used the Public Private Partnership scheme with its cooperation with the private sector through Putrajaya Holdings Sdn Bhd, which was only established in 1995 as the developer, and Kuala Lumpur City Center Bhd as the project manager(Moser, 2010). The total cost incurred by Putrajaya Holdings Sbn Bhd is around RM20 billion (Macedo and Tran, 2013) or around $10.17 \%$ of Malaysia's GDP which is worth RM196, 714 in 1997 (Verma and Dutta, 2013).

This large cost did not burden Malaysia's budget because at that time Malaysia had high reserves from its oil production (Macedo and Tran, 2013). Therefore, even though the construction took place at the time of the Asian financial crisis, Putrajaya could still be resolved. In addition, a strong commitment from the authorities at the time, namely Prime Minister Mahathir made the Putrajaya mega project not experience significant constraints in financing.

Even so, criticism and rejection came from the opposition of the Malaysian Government. However, because of the high commitment of Prime Minister, Mahathir, and the good and structured planning of Putrajaya, the parliament continued to approve the transfer of the central government. The relocation of the capital was successfully held in a government regime, in which Prime Minister, Mahathir, was still in office until the inauguration of Putrajaya as the capital of the Malaysian government.

\subsubsection{Tanzania}

In 1973, the founding father of Tanzania, namely President Julius Nyerere proposed that the capital of Tanzania from Dar es Salaam to Dodoma. The reason for the transfer was partly because Dodoma was considered more accessible because it was located in the center of the country. In addition, Dodoma was also chosen because of its cool climate and a more natural landscape (Kironde, 1993).

In 1974 Dodoma was officially set as the new capital of Tanzania. The Capital Development Authority (CDA), a special body formed to carry out the relocation, also collaborated with the Canadian Company, Project Planning Associates (PPA) which was asked to prepare the master plan for Dodoma development. The Tanzanian government allocated Dodoma development for 10 years since 1976 with a total budget of TShs3.71 billion, equivalent to USD 53 million (Kironde, 1993), around 2.36\% of GDP. The budget comes from the government budget and foreign loans.

Why the move is considered a failure? In fact, there is no major government or economic activity functioning in Dodoma (Akingbade, 2016). Until 2016, only the parliament building and the presidential office were located in Dodoma,while other ministry buildings, government officials, diplomatic and military offices are still located in the previous capital. Dar es Salaam still accommodates about $70 \%$ of industrial activities in Tanzania. In terms of population, the population in Dodoma is less than half the total population in Dar es Salaam, which is 2,083,588 people compared to 4,364,541 people. Three things were the cause of delays in moving the capital to Dodoma, including lack of budget, lack of political will from the Tanzanian government, and poor infrastructure conditions in the new capital's location (Akingbade, 2016). 
After Dodoma could be considered "malfunctioning" as the capital of Tanzania for 41 years, President John Magufuli, who just took office in October 2015, immediately planned to move the capital back to Dodoma during his five-year tenure, namely at the end of 2020 . Prime Minister Kassim Majaliwa acted as the highest supervisor of the project and announced that the transfer would take place from September 2016 (Akingbade, 2016). Prime Minister Majaliwa also ordered his cabinet to join Dodoma, unlike President Nyerere, who seemed to have been abandoned by his stafs.

It is estimated that funds of USD 582.9 million or worth $1.23 \%$ of GDP are needed to actually function Dodoma as the capital of Tanzania (Olinggo, 2016). It is hoped that the effort to realize Dodoma as the capital of Tanzania can overcome the shortage of 3.5 million housing needs in Tanzania. In addition, foreign investors are expected to be increasingly interested in investing in the country. In addition, President Magufuli also hopes that the efficiency and effectiveness of the government can work because it is carried out in a strategic location and can be accessed from all parts of Tanzania.

Table 3 summarizes the lessons learned from Brazil, Malaysia and Tanzania, specifically related to the total costs and mechanisms for financing capital relocations in each of these countries.

\subsection{Financing with Traditional Schemes}

Traditional schemes or financing through state budget can be carried out if he government has sufficient fiscal space. Based on the speakers' explanation, the fiscal space in the current state budget is very little, leaving only $20-22 \%$ because it has been allocated for mandatory spending in the form of education budget (by $20 \%$ ) and health budget (by $5 \%$ ) and other priority programs. Related to the feasibility or not of the fiscal space in accommodating additional budget in the form of capital transfer, this can be done during the loading installments and keep a deficit of below 3\% and enforce spending efficiency. Meanwhile, the budget allocation is entirely the President's prerogative, and there is a cost that must be paid if he chooses to impose the budget for moving the capital to the state budget, which is to shift the priority programs that have been planned in advance or by increasing debt due to increasing deficits.

Table 3. Smart Practices Of Lessons Learned From Capital City Relocation In Brazil, Malaysia, And Tanzania

\begin{tabular}{|c|c|c|c|}
\hline $\begin{array}{l}\text { Related } \\
\text { Aspects }\end{array}$ & $\begin{array}{c}\text { Brazil } \\
\text { (successul) }\end{array}$ & $\begin{array}{l}\text { Malaysia } \\
\text { (successful) }\end{array}$ & $\begin{array}{c}\text { Tanzania } \\
\text { (not successful } \\
\text { yet) }\end{array}$ \\
\hline $\begin{array}{ll}\text { Year } & \text { of } \\
\text { Transfer } & \end{array}$ & $1956-1960$ & $1994-1999$ & $1974-$ now \\
\hline $\begin{array}{l}\text { The location of } \\
\text { the new capital } \\
\text { city }\end{array}$ & $\begin{array}{l}\text { Far away } \\
(915 \mathrm{~km})\end{array}$ & $\begin{array}{l}\text { Closed } \\
\mathrm{km})\end{array}$ & $\begin{array}{l}\text { Far away }(441,6 \\
\mathrm{km})\end{array}$ \\
\hline $\begin{array}{l}\text { Total Cost (\% } \\
\text { of GDP) }\end{array}$ & $2-3 \%$ & $\begin{array}{l}\text { RM20 billion } \\
(10.17 \%)\end{array}$ & $\begin{array}{l}\text { Old: TShs } 3.71 \\
\text { billion }(2.36 \%) \\
\text { New: } \\
\text { USD } \\
\text { million }(1.23 \%)\end{array}$ \\
\hline
\end{tabular}




\begin{tabular}{|c|c|c|c|}
\hline $\begin{array}{l}\text { Related } \\
\text { Aspects }\end{array}$ & $\begin{array}{c}\text { Brazil } \\
\text { (successul) }\end{array}$ & $\begin{array}{c}\text { Malaysia } \\
\text { (successful) }\end{array}$ & $\begin{array}{c}\text { Tanzania } \\
\text { (not successful } \\
\text { yet) }\end{array}$ \\
\hline $\begin{array}{l}\text { Financing } \\
\text { Scheme }\end{array}$ & $\begin{array}{l}\text { Traditional } \\
\text { (government } \\
\text { budget } \\
\text { through } \\
\text { currency } \\
\text { printing and } \\
\text { loans) }\end{array}$ & $\begin{array}{l}\text { Public Private } \\
\text { Partnership }\end{array}$ & $\begin{array}{l}\text { Traditional } \\
\text { (government } \\
\text { budget through } \\
\text { foreign loans) }\end{array}$ \\
\hline
\end{tabular}

As for the urgency and benefits of traditional schemes financing, the government will have better control if the financing of the transfer of the capital city is entirely through the state budget. It is also an obligation for the government to use the state budget in public services that cannot be provided by the private sector and does not attract the private sector to participate.

However, the State Budget should only act as a stimulus so the private sector is expected to play a greater role in infrastructure development in the future. In addition to the existing fiscal constraints given the still low availability of mandatory spending and tax ratio, the excessive involvement of the state budget has the potential to use allocations that should be used to fulfill government promises in the form of strategic programs. In addition, the involvement of the government role that is too far will cause crowding out on the role of the private sector in the provision of infrastructure in Indonesia.

\subsection{Financing With Government-Business Cooperation Schemes}

Implicitly, the capital transfer project is not feasible if it is financed by a PPP scheme in one bundle because it is not included in the infrastructure of Perpres number 38 of 2015. Therefore, it should be done in a breakdown according to the scope of its infrastructure. The project breakdown will also make it easier for the private sector to choose projects that the rate of return are more guaranteed, and are also needed to sort out which projects can be financed by the State Budget or Government-Business Cooperation. Even so, this project actually is allowed for cooperation through Government-Business Cooperation in one bundle, considering that the infrastructure scope clause in Perpres number 38 of 2015 can be expanded.

The main advantage that can be obtained by the government if using GovernmentBusiness Cooperation scheme is to be able to adopt cost efficiency based on the efficiency of the private sector in implementing public services. The government also has the opportunity to do better cash flow management so that fiscal space can be used for other activities.

In addition, there are other benefits from the use of Government-Business Cooperation schemes, which can lighten the burden on the State Budget, working on infrastructure projects is more efficiently, more innovative financing, and increase budget transparency. The use of Government-Business Cooperation schemes is better in terms of cost and time to work than traditional schemes (Liu et al., 2014).

On the other hand, there are several potential losses from the use of GovernmentBusiness Cooperation schemes, among others; the government needs resources that are not 
small, because of the complexity of the project itself. In addition, the government has the potential to lose control of these projects.

\subsection{The Right Financing Scheme}

If only reflecting on the smart practices of Brazil, Malaysia and Tanzania and also projecting the budget for moving the capital city, there is no problem at all if the State Budget fully covers the cost of moving the capital city. From Table 2 that IDR 690 trillion is the total projection of the capital transfer budget, with IDR 420 trillion borne by the State Budget, and IDR 270 trillion borne by the private sector.

When compared to Indonesia's GDP in 2016 (USD 932 billion or equivalent to IDR 13.048 trillion), the total projected budget for capital transfers is equivalent to $5.28 \%$ of GDP, with $3.2 \%$ of GDP borne by the State Budget and $2.08 \%$ of GDP by the private sector. These figures are still reasonable compared to the smart practices of capital transfers by Brazil (2-3\% of GDP), Malaysia (10.17\% of GDP), and Tanzania (2.36\% of old GDP transfers and $1.23 \%$ of GDP New GDP displacement).

Even so if the budget projection is compared to Indonesia's current fiscal space, as the discussion in point $C$, the fiscal space in the current State Budget is $20-22 \%$ of state expenditure, or the value of IDR 444-488.4 trillion. With consideration of the capital transfer plan to be implemented within a period of 30 years, the burden of moving the capital city per year in the State Budget is IDR 14 trillion (without taking into account the costs borne by the private sector) or IDR 23 trillion (if taking into account the costs borne by the private sector). This figure is only $3-4.7 \%$ of the current State Budget fiscal space.

However, the calculation for allocating the capital transfer budget is not as easy and simple as that. The explanation in point $\mathrm{C}$ has more or less illustrated the conditions that must be considered and the potential losses that must be borne by the government if it accommodates the complete relocation of the capital city to the State Budget.

Therefore, based on the nature of each of the existing infrastructure functions and the experiences and competencies of the resource persons, Tables 4 - 6 illustrate the three proposals for the proportion of capital relocation financing schemes. Basically, all resource persons agreed that main functions should be provided by the Government through State Budget. However, it is still possible to finance such functions by using Government-Business Cooperation scheme as other countries like South Korea and England have proved to do so. In terms of support and supporting functions, they all agreed that Government-Business Cooperation scheme ought to take a bigger role than the State Budget.

Table 4. Recapitulation Of Costs And Financing Scheme of Center Of Government Relocation (Version I)

\begin{tabular}{|c|c|c|}
\hline Nc & Funtion & Cost \\
\hline \multicolumn{3}{|c|}{$\begin{array}{l}\text { Funded by the State Budget: IDR } 340 \\
\text { trillion }\end{array}$} \\
\hline 1. & $\begin{array}{l}\text { Main Functions } \\
\text { (Legislative, Executive and } \\
\text { Judicial Buildings) }\end{array}$ & $\begin{array}{l}\text { IDR } 40 \\
\text { trillion }\end{array}$ \\
\hline 2. & $\begin{array}{l}\text { Support Functions } \\
\text { (Housing for Low-Income } \\
\text { Communities, Schools and } \\
\text { universities, Hospitals and }\end{array}$ & $\begin{array}{l}\text { IDR } \\
300 \\
\text { trillion }\end{array}$ \\
\hline
\end{tabular}




\begin{tabular}{|c|c|c|}
\hline No & Funtion & Cost \\
\hline & 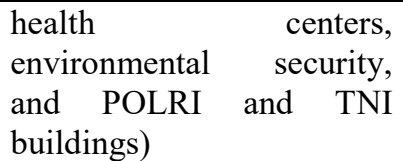 & \\
\hline $\begin{array}{l}\text { Fun } \\
\text { Coo } \\
\text { dep }\end{array}$ & $\begin{array}{l}\text { ed by Government } \\
\text { eration: IDR } 80 \text { trillion ( } \\
\text { ids on investor) }\end{array}$ & $\begin{array}{l}\text {-Business } \\
\text { uarantee }\end{array}$ \\
\hline 1. & 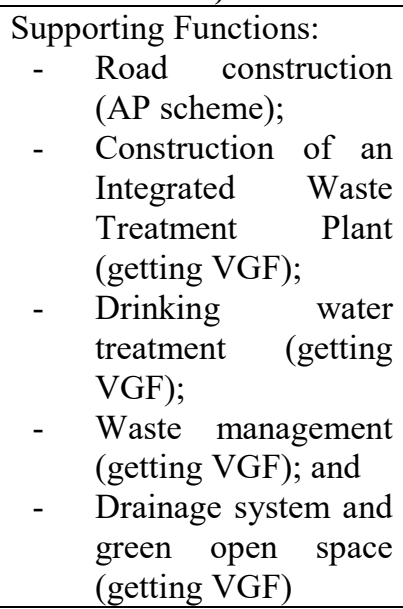 & $\begin{array}{l}\text { IDR } 80 \\
\text { trillion }\end{array}$ \\
\hline \multicolumn{3}{|c|}{$\begin{array}{l}\text { Financed by the private sector: IDR } 270 \\
\text { trillion }\end{array}$} \\
\hline 1. & $\begin{array}{lr}\text { Land and } & \text { Housing (for } \\
\text { supporting } & \text { economic } \\
\text { actors) } & \\
\end{array}$ & $\begin{array}{l}\text { IDR } 50 \\
\text { trillion }\end{array}$ \\
\hline 2. & $\begin{array}{l}\text { Land and Flats / } \\
\text { Apartments (Civil Servants } \\
\text { and family) }\end{array}$ & $\begin{array}{l}\text { IDR } \\
220 \\
\text { trillion }\end{array}$ \\
\hline
\end{tabular}

Table 5. Recapitulation Of Costs And Financing Scheme of Center Of Government Relocation (Version Ii)

\begin{tabular}{|c|c|c|}
\hline No & Fungsi & Biaya \\
\hline \multicolumn{3}{|c|}{$\begin{array}{l}\text { Funded by the State Budget: IDR } 254.8 \\
\text { trillion }\end{array}$} \\
\hline 1. & $\begin{array}{l}\text { Main } \\
\text { (Legislative, Executive } \\
\text { and Judicial Buildings) }\end{array}$ & $\begin{array}{l}\text { IDR } 40 \\
\text { trillion }\end{array}$ \\
\hline 2. & $\begin{array}{l}\text { Support Functions } \\
\text { (Community Health } \\
\text { Center, Environmental } \\
\text { Security, and Indonesian } \\
\text { National Police and } \\
\text { Military Buildings) }\end{array}$ & $\begin{array}{l}\text { IDR } 210 \\
\text { trillion }\end{array}$ \\
\hline
\end{tabular}




\begin{tabular}{|c|c|c|}
\hline 3. & $\begin{array}{l}\text { Supporting Function } \\
\text { (Drainage system) }\end{array}$ & $\begin{array}{l}\text { IDR } 4.8 \\
\text { trillion }\end{array}$ \\
\hline $\begin{array}{l}\text { Funded by Government-Business } \\
\text { Cooperation: IDR } 165.2 \text { trillion (all } \\
\text { received guarantees) }\end{array}$ & \multicolumn{2}{|c|}{ 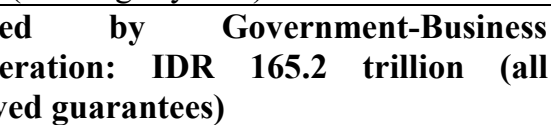 } \\
\hline 1. & \begin{tabular}{lll}
\multicolumn{2}{l}{ Support Functions: } & \\
- & $\begin{array}{l}\text { Housing } \\
\text { (getting VGF) }\end{array}$ & MBR \\
- & $\begin{array}{l}\text { Schools } \\
\text { universities }\end{array}$ & and \\
& (AP \\
scheme) & \\
- & $\begin{array}{l}\text { Hospital } \\
\text { scheme) }\end{array}$ & (AP \\
\end{tabular} & $\begin{array}{l}\text { IDR } 90 \\
\text { trillion }\end{array}$ \\
\hline 1. & 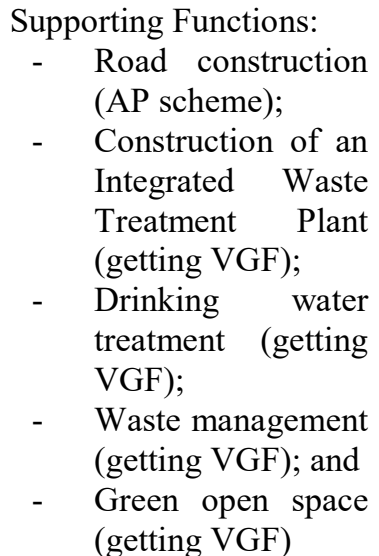 & $\begin{array}{l}\operatorname{Rp} 75,2 \\
\text { trillion }\end{array}$ \\
\hline \multicolumn{3}{|c|}{$\begin{array}{l}\text { Financed by the private sector: IDR270 } \\
\text { trillion }\end{array}$} \\
\hline 1. & $\begin{array}{l}\text { Land and Housing (for } \\
\text { supporting } \\
\text { actors) }\end{array}$ & $\begin{array}{l}\text { IDR50 } \\
\text { trillion }\end{array}$ \\
\hline 2. & $\begin{array}{l}\text { Land and Flats / } \\
\text { Apartments (Civil } \\
\text { Servants and family) }\end{array}$ & $\begin{array}{l}\text { IDR } 220 \\
\text { trillion }\end{array}$ \\
\hline
\end{tabular}

Table 6. Recapitulation Of Costs And Financing Scheme of Center Of Government Relocation (Version Iii)

\begin{tabular}{|c|c|c|}
\hline No & Funtion & Cost \\
\hline \multicolumn{3}{|c|}{$\begin{array}{l}\text { Funded by the State Budget: IDR } 294.4 \\
\text { trillion }\end{array}$} \\
\hline 1. & $\begin{array}{ll}\text { Support } & \text { Functions } \\
\text { (Housing MBR, } & \text { Schools, } \\
\text { Health } & \text { Centers, } \\
\text { Environmental } & \text { Security, } \\
\text { and Indonesian } & \text { National } \\
\text { Police and } & \text { Military }\end{array}$ & $\begin{array}{l}\text { IDR294.4 } \\
\text { trillion }\end{array}$ \\
\hline
\end{tabular}




\begin{tabular}{|c|c|c|}
\hline $\mathrm{No}$ & Funtion & Cost \\
\hline \multicolumn{3}{|c|}{ Buildings) } \\
\hline \multicolumn{3}{|c|}{$\begin{array}{l}\text { Funded by Governme } \\
\text { Cooperation: IDR } 125.6 \text { t } \\
\text { received guarantees) }\end{array}$} \\
\hline 1. & $\begin{array}{lr}\text { Main } & \text { Functions } \\
\text { (Legislative, } & \text { Executive } \\
\text { and Judicial Buildings) }\end{array}$ & $\begin{array}{l}\text { IDR } 40 \\
\text { trillion }\end{array}$ \\
\hline 2. & $\begin{array}{lr}\text { Support } & \text { Functions } \\
\text { (Universities } & \text { and } \\
\text { Hospitals) } & \\
\end{array}$ & $\begin{array}{l}\text { IDR } 5.6 \\
\text { trillion }\end{array}$ \\
\hline 3. & $\begin{array}{l}\text { Supporting Functions: } \\
\text { - } \quad \text { Road construction } \\
\text { (AP scheme); } \\
\text { - Construction of an } \\
\text { Integrated Waste } \\
\text { Treatment Plant } \\
\text { (AP and VGF } \\
\text { scheme); } \\
\text { Drinking water } \\
\text { treatment (AP and } \\
\text { VGF schemes); } \\
\text { Waste management } \\
\text { (AP and VGF } \\
\text { schemes); and } \\
\text { Drainage system } \\
\text { and green open } \\
\text { space (AP and } \\
\text { VGF schemes) }\end{array}$ & $\begin{array}{l}\text { IDR } 80 \\
\text { trillion }\end{array}$ \\
\hline \multicolumn{3}{|c|}{$\begin{array}{l}\text { Financed by the private sector: IDR } 270 \\
\text { trillion }\end{array}$} \\
\hline 1. & $\begin{array}{lr}\text { Land and Housing (for } \\
\text { supporting } \\
\text { actors) }\end{array}$ & $\begin{array}{l}\text { IDR } 50 \\
\text { trillion }\end{array}$ \\
\hline 2. & $\begin{array}{l}\text { Land and Flats / } \\
\text { Apartments (Civil } \\
\text { Servants and family) }\end{array}$ & $\begin{array}{l}\text { IDR } 220 \\
\text { trillion }\end{array}$ \\
\hline
\end{tabular}

\section{Conclusions}

Developing countries such as Brazil and Malaysia which were successful in moving the capital, and Tanzania, which is starting over the relocation, spent a lot of money executing the capital transfer project. About 1-3\% of Brazil and Tanzania's GDP respectively, and 10\% of Malaysia's GDP must be allocated to realize it.

Meanwhile, Brazil and Tanzania chose to allocate all funds from their state budget, or commonly referred to as traditional schemes. On the other hand,Malaysia chose to use a more sophisticated scheme: the Government-Business Cooperation scheme. In Indonesia's plan 
which has projected the total amount of capital transfer costs to be borne by the State Budget of IDR 420 trillion, both schemes are possible to be implemented with their respective advantages and disadvantages.

Therefore, a combination of traditional schemes and Government-Business Cooperation is considered the most appropriate financing scheme to realize the implementation of the capital relocation to new regions. The proportion between the traditional scheme and the ideal Government-Business Cooperation varies in the views of the resource persons, depending on how they view each of the existing infrastructure functions.

There is one aspect that the Indonesian government should not forget referring to the successes and / or failures experienced by Brazil, Malaysia and Tanzania, namely the strong political will of the government. Brazil and Malaysia are considered successful by the international community because of the strong commitment of their leaders to conduct the plan. Poor government commitment resulted in Tanzania's failure to move the capital to Dodoma. This commitment can, among other things, be realized through the preparation of state documents as the basis for the transfer of the central city of government. If Brazil has Plano de Metas and Malaysia has Vision 2020 as the main foundation, on the other hand Tanzania does not have that. Indonesia should also be able to formulate the plan, both in the short-term, medium-term, long-term government plans, or at the level of statutory law.

\section{References}

[1] Akingbade, A. (2016) Exploring Tanzania's move to its 43 year old de facto capital Ventures Africa. Available at: http://venturesafrica.com/exploring-tanzanias-move-toits-43-years-old-de-facto-capital/ (Accessed: 7 January 2019).

[2] Ariyanti, F. (2017) Terkuak Alasan Pemindahan Ibu Kota dari Jakarta ke Kalimantan Bisnis Liputan6.com. Available at: https://www.liputan6.com/bisnis/read/3019787/terkuak-alasan-pemindahan-ibu-kotadari-jakarta-ke-kalimantan (Accessed: 7 January 2019).

[3] Aziza, K. S. (2017) Pemerintah Targetkan Pemindahan Ibu Kota Dimulai 2018 Kompas.com. Available at: https://ekonomi.kompas.com/read/2017/07/03/154128926/pemerintah.targetkan.pemin dahan.ibu.kota.dimulai.2018 (Accessed: 7 January 2019).

[4] Boadway, R. (2006) 'Principles of Cost-Benefit Analyses', Public Policy Review, 2(1), pp. $1-44$.

[5] Daud, A. (2017) Menteri PU Taksir Biaya Pemindahan Ibu Kota Hingga Rp 300 Triliun - Katadata News. Available at: https://katadata.co.id/berita/2017/07/12/menteripu-biaya-pemindahan-ibu-kota-bisa-mencapai-rp-300-triliun (Accessed: 7 January 2019).

[6] Epstein, D. G. (1973) Brasilia, plan and reality; a study of planned and spontaneous urban development. Berkeley: University of California Press.

[7] Fitra, S. (2017) Beragam Cara Mendanai Proyek Infrastruktur. Available at: https://katadata.co.id/berita/2017/10/19/beragam-cara-mendanai-proyek-infrastruktur (Accessed: 7 January 2019).

[8] Gordon, D. (2006) Planning Twentieth Century Capital Cities. London: Routledge.

[9] Gottmann, J. (1997) 'The role of capital cities', Ekistics. Athens Center of Ekistics, pp. 240-243. doi: 10.2307/43618930.

[10] Herbst, J. (2014) States and Power in Africa Comparative Lessons in Authority and Control. Second Edi. Princeton: Princeton University Press. 
[11] Indrawati, S. M. (2018) Kerangka Ekonomi Makro dan Pokok-Pokok Kebijakan Fiskal Tahun Anggaran 2019. Available at: https://www.kemenkeu.go.id/media/9980/pidatomenteri-keuangan-pengantar-dan-keterangan-pemerintah-atas-kerangka-ekonomimakro-dan-pokok-pokok-kebijakan-fiskal-ta-2019.pdf (Accessed: 7 January 2019).

[12] Kironde, J. M. L. (1993) 'Will Dodoma ever be the new capital of Tanzania?', Geoforum, 24(4), pp. 435-453. doi: 10.1016/0016-7185(93)90006-4.

[13] Liu, J., Love, P. E. D., Smith, J., Regan, M. and Sutrisna, M. (2014) 'Public-Private Partnerships: a review of theory and practice of performance measurement', International Journal of Productivity and Performance Management, 64(4), pp. 494519. doi: 10.1108/JFM-03-2013-0017.

[14] Macedo, J. and Tran, L. V. (2013) 'Brasília and Putrajaya: Using urban morphology to represent identity and power in national capitals', Journal of Urbanism, 6(2), pp. 139 159. doi: 10.1080/17549175.2013.820209.

[15] Morshidi, S. and Pandian, S. (2007) 'Globalizing Kuala Lumpur: competitive city strategies under Dr. Mahathir Mohamed', Asian Profile, 35(6), p. 489.

[16] Morten, M. and Oliveira, J. (2016) 'Migration, Roads and Labor Market Integration: Evidence from a Planned Capital City', Working Paper.

[17] Moser, S. (2010) 'Putrajaya: Malaysia's new federal administrative capital', Cities, 27(4), pp. 285-297. doi: 10.1016/j.cities.2009.11.002.

[18] Nababan, C. N. (2018) Pemindahan Ibu Kota Rogoh Kocek Minimal Rpl Triliun. Available at: https://www.cnnindonesia.com/ekonomi/20180104131152-532266665/pemindahan-ibu-kota-rogoh-kocek-minimal-rp1-triliun (Accessed: 7 January 2019).

[19] Olds, K. (1995) 'Globalization and the Production of New Urban Spaces: Pacific Rim Megaprojects in the Late 20th Century', Environment and Planning A. SAGE PublicationsSage UK: London, England, 27(11), pp. 1713-1743. doi: 10.1068/a271713.

[20] Olinggo, A. (2016) Challenges Magufuli faces in moving govt to Dodoma - The East African. Available at: https://www.theeastafrican.co.ke/news/Challenges-Magufulifaces-moving-Tanzania-government-to-Dodoma/2558-3334062-2jpur4z/index.html (Accessed: 7 January 2019).

[21] Oliver, S. D. (2012) 'Putrajaya: A capital for the future', The Unfamiliar:An Antropological Journal, 2(2), pp. 112-113.

[22] Potts, D. (1985) 'Capital Relocation in Africa: The Case of Lilongwe in Malawi', The Geographical Journal. The Royal Geographical Society (with the Institute of British Geographers), 151(2), p. 182. doi: 10.2307/633532.

[23] Prasetya, F. (2012) 'Bagian 1: Peran Pemerintah', in MODUL EKONOMI PUBLIK. Malang: FAKULTAS EKONOMI DAN BISNIS UNIVERSITAS BRAWIJAYA. Available at: http://ferryfebub.lecture.ub.ac.id/files/2013/01/Bagian-I-PeranPemerintah.pdf (Accessed: 7 January 2019).

[24] Quistorff, B. (2015) 'Capitalitis? Effects of the 1960 Brazilian Capital Relocation', SSRN Electronic Journal. doi: 10.2139/ssrn.2588620.

[25] Schatz, E. (2003) When Capital Cities Move: The Political Geography of Nation and State Building.

[26] Sugianto, D. (2017) Sederet Rencana Pindahkan Ibu Kota dari Era Soekarno Hingga Jokowi. Available at: https://finance.detik.com/berita-ekonomi-bisnis/d3471911/sederet-rencana-pindahkan-ibu-kota-dari-era-soekarno-hingga-jokowi (Accessed: 7 January 2019). 
[27] Taufiqqurahman, M. (2017) Ini Alasan Ibu Kota RI Harus Pindah dan 3 Calon Lokasinya. Available at: https://finance.detik.com/berita-ekonomi-bisnis/d3548918/ini-alasan-ibu-kota-ri-harus-pindah-dan-3-calon-lokasinya ～(Accessed: 7 January 2019).

[28] Verma, N. M. P. and Dutta, V. (2013) 'Understanding Recession: Conceptual Arguments and US Adjustments', in Recession and Its Aftermath. India: Springer India, pp. 1-22. doi: 10.1007/978-81-322-0532-6_1.

[29] Veselý, A. (2011) 'Theory and Methodology of Best Practice Research: A Critical Review of the Current State', Central European Journal of Public Policy, 5(2), pp. 98117. Available at: http://www.cejpp.eu/index.php/ojs/article/view/99/81. 